\title{
Az atorvastatin/amlodipin fix kombináció versus az atorvastatinterápia a terápiahüség tükrében
}

\author{
Simonyi Gábor dr. ${ }^{1}$ - Ferenci Tamás dr. ${ }^{2}$ \\ ${ }^{1}$ Szent Imre Egyetemi Oktatókórház, Anyagcsere Központ, Budapest \\ ${ }^{2}$ Óbudai Egyetem, Neumann János Informatikai Kar, Élettani Szabályozások Csoport, Budapest
}

\begin{abstract}
Bevezetés: A hypertonia és a dyslipidaemia módosítható cardiovascularis kockázati tényezők. Hazánkban a hypertonia és a dyslipidaemia egyaránt népbetegségnek számítanak. A célértékek elérésében a hatékony vegyületek alkalmazásán túlmenően a betegek terápiahűsége alapvető fontosságú. Célkitüzés: Az atorvastatin/amlodipin fix kombináció egyéves perzisztenciájának összehasonlítása az atorvastatinterápiához képest. Módszer: Az Országos Egészségbiztosítási Pénztár adatbázisából a vényforgalmi adatokra támaszkodva 2012. október 1. és 2013. szeptember 30. közötti időszakban első alkalommal atorvastatin/amlodipin fix kombináció, illetve az atorvastatin hatóanyagú készítmények bármely dózisának receptjét kiváltó betegeket választottak ki, akik a megelőző egy évben hasonló terápiában nem részesültek. A perzisztencia modellezésére a túlélésanalízis klasszikus eszköztárát alkalmazták, ahol a „túlélési” idő a gyógyszer szedésének abbahagyásáig eltelt idő volt. A modellezéshez komplementer log-log link függvényt használó általánosított lineáris modellt alkalmaztak mint diszkrét túléléselemzési modellt. Eredmények: A vizsgált időszakban 24433 beteg kezdett atorvastatin/amlodipin fix kombinációt, míg 192579 beteg atorvastatinterápiát. A megfigyelési időszakban az atorvastatin/amlodipin fix kombináció egyéves perzisztenciája 43\%, míg az atorvastatinterápiáé $21 \%$ volt. Az atorvastatin/amlodipin fix kombináció átlagos perzisztencia-időtartama 221,4 (SE: 0,894) napnak bizonyult, míg az atorvastatinterápiáé 153,0 nap (SE: 0,297) volt a vizsgált időszakban. Az atorvastatinterápia abbahagyásának kockázata az atorvastatin/amlodipin fix kombinációhoz képest majdnem kétszeresen nagyobbnak bizonyult $(\mathrm{HR}=1,85,95 \%$ CI 1,82-1,89, p<0,0001). Következtetések: A szerzők megállapították, hogy az atorvastatin/ amlodipin fix kombináció egyéves perzisztenciája lényegesen magasabb (mintegy kétszerese) az atorvastatin-monoterápiához képest, ezért a kettős célérték elérése szempontjából különösen kedvező az atorvastatin/amlodipin fix kombináció alkalmazása. Orv. Hetil., 2016, 157(11), 425-429.
\end{abstract}

Kulcsszavak: terápiahúség, perzisztencia, atorvastatin/amlodipin fix kombináció, célértékek

\section{One year persistence of atorvastatin and amlodipine fixed dose combination versus atorvastatin therapy}

Introduction: Hypertension and dyslipidemia are modifiable cardiovascular risk factors. In Hungary hypertension and dyslipidemia are quite frequent conditions. The patients' adherence is very important factor to reach the targets. Aim: The aim of the authors was to investigate the one-year persistence of the atorvastatin therapy and atorvastatin and amlodipine fixed dose combination. Method: National Health Insurance Found prescriptions database of Hungary on pharmacy claims between October 1, 2012 and September 30, 2013 was analyzed. The authors identified patients who filled prescriptions for atorvastatin and amlodipine fixed dose combination and atorvastatin prescribed for the first time. Patients did not receive similar drugs for one year before the study. To model the persistence, the apparatus of survival analysis was used, where "survival" was the time to abandon the medication. As it was available to month precision, discrete time survival analysis was applied: a generalized linear model was estimated with complementary log-log link function with the kind of drug being the only explanatory variable. Results: During the trial period, atorvastatin and atorvastatin plus amlodipine fixed dose combination was started in 192,579 and 24,433 patients, respectively. One year persistence rate in patients with atorvastatin and amlodipine fixed dose combination was $43 \%$, and $21 \%$ in patients with atorvastatin therapy. The 360 -days-restricted study period, the mean duration of persistence was 221.4 (SE: 0.894) days in patients on atorvastatin and amlodipine fixed dose combination and 153.0 days (SE: 0.297 ) in those on atorvastatin regimen. The hazard of discontinuation was almost twofold higher during treatment with atorvastatin therapy compared with the use of the atorvastatin and amlodipine fixed dose combina- 
tion (hazard ratio $=1.85, \mathrm{p}<0.0001)$. Conclusions: There is a significant difference between the one-year persistence of atorvastatin therapy and atorvastatin plus amlodipine fixed dose combination. The result demonstrate that atorvastatin and amlodipine fixed dose combination is favourable to reach double goals on blood pressure and LDLcholesterol.

Keywords: adherence, persistence, atorvastatin/amlodipin fixed dose combination, targets

Simonyi, G., Ferenci, T. [One year persistence of atorvastatin and amlodipine fixed dose combination versus atorvastatin therapy]. Orv. Hetil., 2016, 157(11), 425-429.

(Beérkezett: 2016. január 21.; elfogadva: 2016. február 14.)

\section{Rövidítések}

ASCOT-LLA = Anglo-Scandinavian Cardiac Outcomes Trial - Lipid Lowering Arm; BNO = Betegségek Nemzetközi Osztályozása; $\mathrm{CCB}=$ kalciumcsatorna-blokkoló; $\mathrm{CI}=$ konfidenciaintervallum; CUSP $=$ Caduet in an Untreated Subject Population; $\mathrm{HR}=$ (hazard ratio) kockázati arány; MRFIT = Multiple Risk Factor Intervention Trial; NO = nitrogén-monoxid; OEP = Országos Egészségbiztosítási Pénztár; OPAL = OPtimális cardiovascularis rizikócsökkentés Atorvastatin és AmlodipinLisinopril kombinációval; $\mathrm{SE}=($ standard error $)$ standard hiba

A cardiovascularis betegségek hazánkban a vezető haláloki tényezők. A számos módosítható cardiovascularis kockázati tényezők közül a hypertonia és a dyslipidaemia gyakran együtt jelentkezik. A hypertoniások több mint felében legalább két más cardiovascularis kockázati tényező is jelen lehet [1]. Az együttesen fennálló kockázati tényezők káros szív- és érrendszeri hatásai nem egyszerűen összeadódnak, hanem megtöbbszöröződhetnek. A nagy cardiovascularis kockázattal járó metabolikus szindróma elemei közé tartozik többek között a hypertonia és a dyslipidaemia.

A legújabb adatok szerint az Egyesült Államokban a 20 évesnél idősebbek körében a magas LDL-koleszterinszinttel (>5,2 mmol/l) rendelkezők aránya 33,5\%, míg a magas vérnyomásban szenvedók aránya $32,6 \%$ volt. A kóros LDL-koleszterin-szinttel rendelkezók csak 48,1\%-át kezelték, és e betegek csak mintegy harmada $(29,5 \%)$ érte el az LDL-célértékeket. A magas vérnyomású betegek $82,7 \%$-a ismert, és mintegy háromnegyedük $(76,5 \%)$ részesült antihipertenzív terápiában, és e betegek 54,1\%-a megfelelően kontrollált [2-5].

Hazánkban a felnőtt lakosság mintegy 35,2\%-át érinti a magasvérnyomás-betegség [6]. Az EUROASPIRE III adatai szerint hazánkban a vérnyomáscsökkentő kezelésben részesülők $45,9 \%$-a van célértéken, ez a lipidcélokat illetően 50,4\%-ot jelent [7]. A Magyar Hypertonia Regiszterben a magas vérnyomásban szenvedők 33\%-ában észleltek 2-es típusú cukorbetegséget, 62\%-ában magas koleszterinszintet és 40-60\%-ában hasi típusú elhízást. Hazai adatok szerint a hypertoniások közel $50 \%$-a nem éri el a célvérnyomást [8]. A kettős célérték elérésének nehézségeit jelzi, hogy az Egyesült Államokban hyperto- nia és dyslipidaemia együttes jelenlétekor a betegek csak mintegy $10 \%$-a éri el az együttes célértéket [9].

Az MRFIT vizsgálatban évtizedekkel ezelőtt igazolták, hogy az összkoleszterinszint és a szisztolés vérnyomás együttes emelkedése kifejezetten növeli a coronariaesemények előfordulását [10].

Emberson és mtsai 24 angliai város háziorvosi praxisaiban 40-59 éves betegeket követtek 10 évig és azt találták, hogy az összes cardiovascularis esemény $80 \%$-áért a hypertonia, a hypercholesterinaemia és a dohányzás volt a felelős. A hypertonia és a hypercholesterinaemia együttes jelenléte kilencszeresére emelte a betegek cardiovascularis kockázatát azokhoz képest, akiknél e két tényező nem volt jelen [11].

Korábban hazai adatok nem álltak rendelkezésre az atorvastatin/amlodipin fix kombináció terápiahúségéről. Vizsgálatunkban azt a célt tûztük ki magunk elé, hogy ennek tanulmányozásán túl az atorvastatin/amlodipin fix kombináció egyéves terápiahûségét összehasonlítjuk az atorvastatinterápiáéval.

\section{Betegek és módszer}

Az Országos Egészségbiztosítási Pénztár (OEP) adatbázisának adatait használtuk retrospektív vizsgálatunkban. Az adatbázisból azokat a betegeket választottuk ki, akik 2012. október 1. és 2013. szeptember 30-a között váltottak ki atorvastatin/amlodipin fix kombináció vagy atorvastatin hatóanyagú bármely dózisait tartalmazó recepteket. Az elemzésből kizártuk azokat a betegeket, akik hasonló készítmények receptjeit váltották ki a megelőző 365 napban, a fennmaradó betegek ezért új gyógyszerszedőknek voltak tekinthetők. Minden beteg receptkiváltását 14 hónapig követtük. A követési időszak alatt elhalálozott betegeket kizártuk elemzésünkből. Hatvannapos gyógyszerkihagyást toleráltunk (grace periódus). A gyógyszerkiváltás egyéves követése során azt tanulmányoztuk, hogy a betegek mekkora hányada maradt atorvastatin/amlodipin fix kombináción, illetve az atorvastatinterápián. A betegek gyógyszerkiváltási adatai 30 napos időközönként álltak rendelkezésre, ezért ennek alapján számoltuk ki a perzisztens betegek számát és arányát. 
$\mathrm{Az}$ atorvastatin/amlodipin fix kombináció és az atorvastatinterápia perzisztencia modellezésére a túlélésanalízis klasszikus eszköztárát alkalmaztuk, ahol a „túlélési idő" a gyógyszer szedésének kezdetétől annak abbahagyásáig eltelt idő volt. Vizsgálatunkban az egyedüli magyarázó változó a terápia (fix kombináció vagy monoterápia) típusa volt. A perzisztenciaadatok 30 napos frekvenciával voltak elérhetők, ezért diszkrét idejű túlélést becsültünk meg, majd ábrázoltuk az idő függvényében. A modellezéshez komplementer log-log link függvényt használó általánosított lineáris modellt becsültünk, amely a jól ismert (folytonos idejű) túléléselemzés bevált diszkrét idejű megfelelője [12]. A gyógyszerek között a hazárd proporcionalitását olyan módon ellenőriztük, hogy hozzáadtuk a modellhez a gyógyszer és az eltelt idő interakcióját, és összehasonlítottuk ennek a - szaturált - modellnek az illeszkedését az eredeti modellével [13]. Amennyiben a nem proporcionalitás nem volt jelentős, úgy meghatároztuk a gyógyszerszedés abbahagyásának hazárdját (hazárd arány - $\mathrm{HR}$ ) is, az atorvastatin/amlodipin fix kombinációhoz hasonlítva. Kiszámoltuk mindkét készítmény szedésének a 12 hónapra korlátozott átlagos túlélési idejét [14] is.

\section{Eredmények}

2012. október 1. és 2013. szeptember 30. között 24433 beteg kezdett atorvastatin/amlodipin fix kombinációt, míg 192579 beteg atorvastatinterápiát.

$\mathrm{Az}$ atorvastatinterápiát az első hónap után a betegek 34\%-a, míg a harmadik hónapra a betegek majdnem fele (47\%) hagyta el. Fél év elteltével a nonadherens betegek aránya $69 \%$ volt, azaz a betegek csak $31 \%$-a maradt atorvastatinkezelésen. Az atorvastatinterápia egyéves perzisztenciája $21 \%$ volt.

Az atorvastatin/amlodipin fix kombináció esetében az első hónapra a terápiaelhagyók aránya $15 \%$ volt, a harmadik hónapra ez 32\%-ra nőtt, míg a perzisztens betegek aránya fél év múlva $54 \%$ volt. Az atorvastatin-monoterápiához képest az atorvastatin/amlodipin fix kombináció perzisztenciaelőnye ekkor 23 százalékpont volt. Az atorvastatin/amlodipin fix kombináció egyéves perzisztenciája 43\%-nak bizonyult, amely azt jelentette, hogy a féléves adatokhoz hasonlóan az atorvastatin/amlodipin fix kombináció perzisztenciaelőnye megmaradt (1.ábra).

A 360 napra korlátozott intervallumból számolt átlagos perzisztenciaidő 153,0 (SE: 0,297) nap volt az atorvastatin, míg 221,46 (SE: 0,894) nap az atorvastatin/ amlodipin fix kombináció esetén.

A diszkrét túléléselemzési modell eredményei szerint a nemproporcionalitás ezrelék alatti volt, ezért alkalmazhattuk a proporcionális modellt és ennek révén a HR-t. $\mathrm{Az}$ atorvastatinterápia elhagyásának a hazárdja az atorvastatin/amlodipin fix kombinációhoz képest majdnem kétszeresnek bizonyult $(\mathrm{HR}=1,85$ [95\% CI: 1,821,89], $\mathrm{p}<0,0001$ ) (1. ábra).

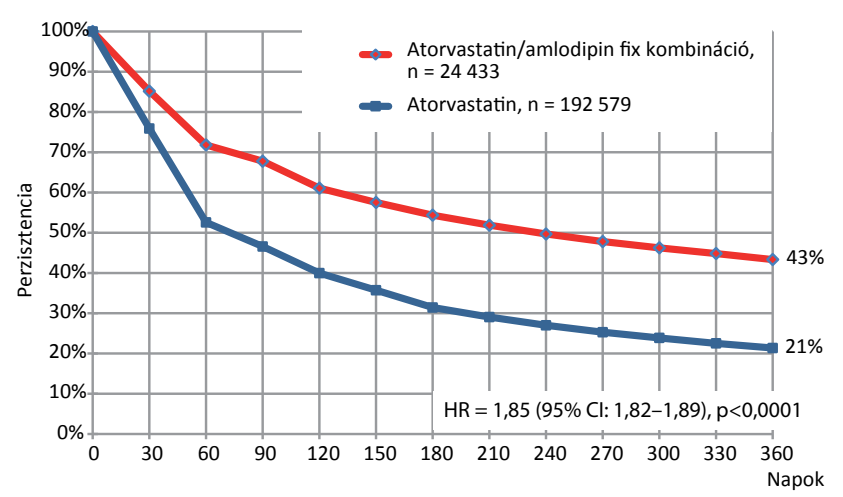

1. ábra

Az atorvastatin/amlodipin fix kombináció és az atorvastatin egyéves perzisztenciája

\section{Megbeszélés}

Eredményeink igazolták, hogy a kettős célérték (vérnyomás és lipid) elérésében kiemelkedő szerepe lehet az atorvastatin/amlodipin fix kombináció hazai viszonylatban kiemelkedő terápiahüségének. Az atorvastatin/ amlodipin fix kombináció egyéves perzisztenciaelőnye 22 százalékponttal haladja meg az atorvastatinterápiáét. Mindez azt jelenti, hogy az atorvastatint az amlodipinnel fix kombinációban alkalmazva szignifikánsan jobb lesz a terápiahüség. Az atorvastatinterápia elhagyásának kockázata majdnem kétszerese az atorvastatin/amlodipin fix kombinációéhoz képest. Még nem publikált eredményeink szerint az atorvastatin/amlodipin fix kombináció egyéves perzisztenciája az amlodipin-monoterápiáét négy százalékponttal felülmúlja.

Más hazai vizsgálatok hiányában eredményeinket egy nemzetközi tanulmánnyal tudjuk csak összehasonlítani. Patel és mtsai egy retrospektív, 4703 beteg bevonásával elvégzett vizsgálatban értékelték az újonnan felírt CCBés statinterápia adherenciáját egy 6 hónapos megfigyelési időszakban. A betegek 16,9\%-a atorvastatin/amlodipin fix kombinációt, 15,6\%-a atorvastatin és amlodipin szabad kombinációt, 24,7\%-a más statint és amlodipint, 13,9\%-a atorvastatint és más CCB-t, míg a többi beteg $(28,9 \%)$ más statint és más CCB-t kapott. A hat hónapos perzisztencia az atorvastatin/amlodipin fix kombinációt szedőkben volt a legjobb $(67,7 \%)$, amelyet 49,9\%-kal atorvastatin és amlodipin szabad kombináció követett, míg 37,4\%-os arányt értek el a más statint és más CCB-t szedő betegek. Többváltozós analízissel az atorvastatin/ amlodipin fix kombináció szignifikáns előnyét igazolták az összes többi nem fix kombinációval szemben [15]. Ezek az eredmények azt mutatják, hogy az Egyesült Államokban az atorvastatin/amlodipin fix kombináció perzisztenciája 12,7 százalékponttal volt magasabb a hazainál. Megjegyzendő, hogy más készítményeknél - a nemzetközi adatokhoz képest - lényegesen rosszabb a hazai terápiahűség, ezért ez a magyarországi adat egyáltalán nem lebecsülendő eredmény [16]. 


\section{Az atorvastatin/amlodipin kombináció hatásossága}

A kalciumcsatorna-blokkolók és a statinok együttes alkalmazásakor az antioxidáns és gyulladásellenes hatásaik miatt szinergista hatást gyakorolnak nemcsak az új atheroscleroticus laesiók kialakulásának gátlásában, hanem a koszorúserekben már kialakult atheroscleroticus laesiók progressziójának megakadályozásában is. Az amlodipin és az atorvastatin együttes adásakor additív módon nő az endothelialis NO-koncentráció és csökkent az oxidatív stressz [17].

Az ASCOT-LLA vizsgálatban a perindopril + amlodipin kombinációhoz adott atorvastatin - a placebóhoz képest - 36\%-kal nagyobb mértékben csökkentette a halálos cardiovascularis események gyakoriságát. A vizsgálat kezdete után átlagosan 11 évvel (8 évvel a vizsgálat zárását követően) az eredetileg atorvastatint szedőkben a bármely eredetű halálozás még szignifikánsan, 14\%-kal volt alacsonyabb a placebót szedőkhöz képest [18].

Az ASCOT-LLA után több vizsgálatot végeztek az amlodipin/atorvastatin kombináció együttes hatásainak felmérésére. A Gemini vizsgálatban az amlodipin/atorvastatin fix kombináció hatásosságát mérték fel a vérnyomás- és a lipidcélértékek együttes elérésének vonatkozásában. A 14 hetes nyílt, multicentrikus vizsgálat végére a dózistitrálások után a betegek átlagosan $7,1 \mathrm{mg}$ amlodipint és 26,2 mg atorvastatint kaptak, és az együttes célértékeket (vérnyomás és LDL-koleszterin) a betegek 51,9\%-a érte el [19].

Egy placebokontrollált, randomizált vizsgálatban (Respond) 1660 hypertoniás betegnek adtak amlodipin/atorvastatin különböző dózisait tartalmazó fix kombinációt, illetve placebót. A 8 hetes kezelés után dózisdependens csökkenés következett be az aktívan kezeltekben a vérnyomás és az LDL-koleszterin, valamint a Framingham-kockázat vonatkozásában [20].

A CUSP vizsgálatban hypertoniás és dyslipidaemiás betegeknél életmód-terápiát alkalmaztak, amelyet a betegek egyik csoportjában atorvastatin/amlodipin fix kombinációval egészítettek ki. A kettős célértéket a betegek 55,6\%-a érte el 8 hetes kezelést követően, szemben a placebocsoport 5\%-ával $(\mathrm{p}<0,001)$ [21].

Egy hazai vizsgálatban 2606 dyslipidaemiás hypertoniás beteg kapott kombinált antihipertenzív és lipidcsökkentő kezelést, amelyben a betegek az atorvastatin/amlodipin fix kombináció több dózisvariációját kapták. A bevonási kritérium a célérték feletti vérnyomás és lipidértékek együttes jelenléte volt. A vizsgálat hat hónapja során a vérnyomás átlagértéke 155,9/90,18 Hgmm-ről - szignifikánsan - 132,77/80,04 Hgmm-re csökkent, miközben a vérnyomáscélértéket a betegek $86,5 \%$-a elérte. Mindezek mellett a lipidprofil befolyásolása is sikeresnek bizonyult. Az összkoleszterinszint 5,97 mmol/l-ról 4,68 mmol/l-re, az LDL-koleszterin-szint 3,45 mmol/ 1-ről 2,49 mmol/1-re, míg a trigliceridszint 2,1 mmol/1- ről 1,69 mmol/l-re csökkent $(\mathrm{p}<0,0001$ minden esetben). A tíz évre vonatkoztatott európai (Heart Score) cardiovascularis kockázat becslési eredménye mindkét nemben, minden korcsoportban, a dohányzó és a nem dohányzó egyének csoportjában egyaránt szignifikáns százalékos kockázatcsökkenést mutatott [22].

\section{Következtetések}

A hypertonia és dyslipidaemia együttes fennállása során a vérnyomás- és a lipidcélértékek elérése nagy jelentőségű a későbbi cardiovascularis események kialakulásának megelőzésében. Az antihipertenzív és az antilipaemiás kezelés során ismert, hogy a betegek jelentős része nem részesül kezelésben, másrészt a kezelt betegek nagy aránya nem éri el a célértékeket. Mindezek mellett nagy jelentőségű a beteg-együttmúködés kérdése, mivel a betegeknek folyamatos - akár élethosszig tartó - kezelésre van szükségük. Az atorvastatin/amlodipin fix kombináció alkalmazásával - szinergista hatásaik útján - csökkenthető az atherosclerosis progressziója, miközben a vérnyomás- és lipidcélértékek is nagyobb arányban érhetôk el. Mindezek mellett az atorvastatin/amlodipin fix kombináció terápiahúsége lényegesen meghaladja az atorvastatinterápiáét, továbbá magasabb az amlodipinterápiánál is. Ezért az atorvastatin/amlodipin fix kombináció alkalmazása jelentős szerepet játszhat a cardiovascularis prevencióban.

\section{Limitációk}

Vizsgálatunkban retrospektív módon elemeztük az OEP adatbázisát. Módszerünkből adódóan nem tudtuk figyelembe venni a primer nonadherenciát (vizsgálatunk tárgya nem ez volt).

A perzisztenciaadatokat nem tudtuk a vizsgálatba belépés - első vénykiváltás - időpontja szerint megbontani: adatbázisunkban csak összesítve volt elérhető az utánkövetési idő. (Tehát ugyanúgy az 1 éves perzisztenciába tartozott az, aki 2012. október l-jétől 2013. szeptember 30-ig volt perzisztens, és az, aki 2013. szeptember 30tól 2014. szeptember 29-ig.) Emiatt a vizsgálati periódus alatti esetleges, perzisztenciát befolyásoló tényezőkben történt változásokat nem tudtuk vizsgálni.

Nem állt rendelkezésünkre adat a potenciális confounderekről, azaz azokról a változókról, amelyek egyszerre befolyásolhatják mind a gyógyszerrendelést, mind az adherenciát (például nem, életkor, szocioökonómiai státusz, betegségsúlyosság).

Anyagi támogatás: A szerzők anyagi támogatásban nem részesültek.

Szerzôi munkamegosztás: S. G.: A vizsgálat hipotézisének kidolgozása, adatgyüjtés megtervezése, kézirat megszö- 
vegezése. F. T.: A vizsgálat adatainak statisztikai feldolgozása, az ehhez kapcsolódó módszerek ismertetése, kézirat szövegezése. A cikk végleges változatát mindkét szerző elolvasta és jóváhagyta.

Érdekeltségek: A szerzőknek nincsenek érdekeltségeik.

\section{Irodalom}

[1] Kannel, W. B.: Risk stratification in hypertension: new insights from the Framingham Study. Am. J. Hypertens., 2000, 13(1 Pt 2), 3S-10S.

[2] Papadopoulos, D. P., Papademetriou, V.: Resistant hypertension: diagnosis and management. J. Cardiovasc. Pharmacol. Ther., 2006, $11(2), 113-118$.

[3] Fields, L. E., Burt, V. L., Cutler, J. A., et al.: The burden of adult hypertension in the United States 1999 to 2000: a rising tide. Hypertension, 2004, 44(4), 398-404.

[4] Moser, M., Franklin, S. S.: Hypertension management: results of a new national survey for the Hypertension Education Foundation: Harris Interactive. J. Clin. Hypertens. (Greenwich), 2007, $9(5), 316-323$

[5] Mozaffarian, D., Benjamin, E. J., Go, A. S., et al.: Heart disease and stroke statistics - 2016 update: a report from the American Heart Association. Circulation, 2016, 133(4), e38-e360.

[6] Kékes, E.: Prevalence of hypertension in Hungary based on the WHO's data 2014. [A hypertonia prevalenciája a világban és hazánkban a 2014-es WHO adatbázis alapján.] Hypertonia és Nephrologia, 2015, 19(6), 265-266. [Hungarian]

[7] Kotseva, K., Wood, D., De Backer, G., et al., EUROASPIRE Study Group: EUROASPIRE III: a survey on the lifestyle, risk factors and use of cardioprotective drug therapies in coronary patients from 22 European countries. Eur. J. Cardiovasc. Prev. Rehabil., 2009, 16(2), 121-137.

[8] Kékes, E.: The importance of combined antihypertensive and antilipid therapy in general practices. [A kombinált antihypertensiv és antilipid kezelés a mindennapi gyakorlatban.] Hypertonia és Nephrologia, 2009, 13(1), 3-10. [Hungarian]

[9] Kostis, J. B.: The importance of managing hypertension and dyslipidemia to decrease cardiovascular disease. Cardiovasc. Drugs Ther., 2007, 21(4), 297-309.

[10] Neaton, J. D., Wentworth, D.: Serum cholesterol, blood pressure, cigarette smoking and death from coronary heart disease. Overall finding and differences by age for 316.099 white men. Arch. Intern. Med., 1992, 152(1), 56-64.

[11] Emberson, J. R., Whincup, P. H., Morris, R. W., et al.: Re-assessing the contribution of serum total cholesterol, blood pressure and cigarette smoking to the aetiology of coronary heart disease: impact of regression dilution bias. Eur. Heart J., 2003, 24(19), $1719-1726$
[12] Mills, M.: Introducing survival and event history analysis. Sage Publications, London, 2011.

[13] Willett, J. B., Singer, J. D.: Investigating onset, cessation, relapse, and recovery: why you should, and how you can, use discretetime survival analysis to examine event occurrence. J. Consult. Clin. Psychol., 1993, 61(6), 952-965.

[14] Royston, P., Parmar, M. K.: Restricted mean survival time: an alternative to the hazard ratio for the design and analysis of randomized trials with a time-to-event outcome. BMC Med. Res. Methodol., 2013, 13, 152.

[15] Patel, B. V., Leslie, R. S., Thiebaud, P., et al.: Adherence with single-pill amlodipine/atorvastatin vs two-pill regimen. Vasc. Health Risk Manag., 2008, 4(3), 673-681.

[16] Simonyi, G., Ferenci, T.: Patient adherence with fixed doses combination of ezetimibe and simvastatin behind the results of IMPROVE-IT trial. [Az ezetimib/simvastatin fix kombináció és a terápiahúség az IMPROVE-IT vizsgálat hátterében.] Metabolizmus, 2015, 13(1), 64-71. [Hungarian]

[17] Mason, R. P., Kubant, R., Heeba, G., et al.: Synergistic effect of amlodipine and atorvastatin in reversing LDL-induced endothelial dysfunction. Pharm. Res., 2008, 25(8), 1798-1806.

[18] Sever, P. S., Chang, C. L., Gupta, A. K., et al.: The Anglo-Scandinavian Cardiac Outcomes Trial: 11-year mortality follow-up of the lipid-lowering arm in the UK. Eur. Heart J., 2011, 32(20), 2525-2532.

[19] Blank, R., LaSalle, J., Reeves, R., et al.: Single-pill therapy in the treatment of concomitant hypertension and dyslipidemia (the amlodipine/atorvastatin Gemini Study). J. Clin. Hypertens. (Greenwich), 2005, 7(5), 264-273.

[20] Preston, R. A., Harvey, P., Herfert, O., et al.: A randomized, placebo-controlled trial to evaluate the efficacy, safety, and pharmacodynamic interaction of coadministered amlodipine and atorvastatin in 1660 patients with concomitant hypertension and dyslipidemia: the Respond trial. J. Clin. Pharmacol., 2007, $47(12), 1555-1569$.

[21] Neutel, J. M., Bestermann, W. H., Dyess, E. M., et al.: The use of a single-pill calcium channel blocker/statin combination in the management of hypertension and dyslipidemia: a randomized, placebo-controlled, multicenter study. J. Clin. Hypertens. (Greenwich), 2009, 11(1), 22-30.

[22] Kékes, E.: The success of fixed combined amlodipine/atorvastatin $\left(\right.$ Amlator $\left.^{\circledR}\right)$ therapy in patients with hypertension and dyslipidemia. [A fix kombinációban adott amlodipin/atorvastatin (Amlator $\left.^{\circledast}\right)$ kezelés sikere dyslipidaemiás hypertoniás betegekben.] Hypertonia és Nephrologia, 2013, 17(1), 19-27. [Hungarian]

(Simonyi Gábor dr., Budapest, Tétényi út 12-16., 1115 e-mail: bmbel3@gmail.com) 